\title{
EFEKTIFITAS EDUKASI MANAJEMEN MANDIRI DALAM PENGENDALIAN KADAR GLUKOSA DARAH DIABETESI TIPE 2
}

\author{
Diana Tri Lestari* \\ Tuti Anggarawati**
}

*) Akper Kesdam IV/Diponegoro, Jalan Hos Cokroaminoto no.4 Semarang, 08156537538,diana.trilestari@yahoo.com

**) Akper Kesdam IV/Diponegoro Semarang, Jalan Hos Cokroaminoto No.4 Semarang, 081390853033, tutianggarawatizumaro@yahoo.com

Corresponding Author: Diana Tri Lestari

\begin{abstract}
Abstrak
Diabetes mellitus merupakan masalah yang kompleks karena berdampak pada aspek fisik, psikologi, dan sosial diabetesi. Salah satu upaya untuk merubah perilaku diabetesi adalah memberikan informasi yang adekuat tentang manajemen mandiri seperti pengaturan diet, latihan fisik, manajemen terapi, pemantauan kadar glukosa darah mandiri serta manajemen stress. Penelitian ini bertujuan untuk mengetahui efektifitas edukasi manajemen mandiri dalam mengendalikan kadar glukosa darah pada diabetesi tipe 2. Penelitian ini menggunakan pendekatan eksperimen kuasi dengan pendekatan pretest-posttest control group. Analisis bivariat dilakukan dengan menggunakan uji paired t-test. Hasil penelitian menunjukkan bahwa edukasi manajemen mandiri DM berpengaruh terhadap pengendalian kadar glukosa darah pada diabetesi tipe 2 kelompok intervensi dengan nilai $\rho=0,004, \propto<0,05$. Sementara pada hasil pengukuran pre dan post test kadar glukosa darah pada diabetesi tipe 2 kelompok kontrol tidak menunjukkan perbedaan signifikan dengan nilai $p=0.09, \propto>0,05$. Rumah sakit dan layanan kesehatan primer disarankan untuk menerapkan edukasi manajemen mandiri supaya kualitas hidup diabetesi menjadi semakin lebih baik.
\end{abstract}

Kata kunci: Diabetes Mellitus, Edukasi, Self-Management

\section{PENDAHULUAN}

International Diabetes Federation (IDF) menyatakan bahwa penduduk dunia saat ini yang mengalami Diabetes Mellitus (DM) sebanyak 387 juta orang. Angka tersebut diperkirakan akan mengalami peningkatan sebesar 55\% atau sebesar 592 juta orang mengalami DM pada tahun 2035. Prevalensi DM di Indonesia juga diperkirakan akan mengalami peningkatan dari 8,5 juta menjadi 14,1 juta ditahun 2035. Perkembangan DM di Asia Tenggara cukup cepat, 1 diantara 12 orang dewasa mengalami DM dan di Dunia setiap 7 detik orang meninggal akibat DM (IDF, 2014). 
DM merupakan suatu bentuk kelainan kronik dan progresif yang ditandai dengan ketidakmampuan tubuh dalam metabolisme karbohidrat, lemak dan protein yang dapat memicu terjadinya hiperglikemia (Black, Hawks, \& Keene, 2009). DM merupakan masalah yang kompleks karena berdampak pada aspek fisik, psikologi, dan sosial diabetesi, bahkan lebih luas imbasnya terhadap keluarga dan masyarakat (Ardakani \& Rashidi, 2005). Komplikasi DM dapat berupa gangguan kardiovaskuler dengan prevalensi mencapai $30.1 \%$, serebrovaskuler $6.8 \%$, neuropati $17.8 \%$, nefropati $10.7 \%$, lesi okuler $14.8 \%$ dan masalah kaki 0.8\% (Zhaolan et al. 2010). Dampak DM akan memperburuk kualitas hidup bahkan kematian, sehingga upaya penanggulangan perlu segera dilakukan. Bentuk penanggulangan difokuskan untuk mencegah terjadinya hiperglikemia yang merupakan penyebab utama terjadinya komplikasi. Strategi yang perlu dilakukan secara terus menerus adalah edukasi perawatan mandiri dan dukungan karena sangat berpotensi untuk mencegah terjadinya komplikasi akut maupun kronis (ADA, 2015).

Informasi tentang diabetes yang kurang merupakan salah satu faktor penyebab hambatan dalam perawatan mandiri hambatan dalam perawatan mandiri diabetesi selain faktor fisik, psikologis, sosial dan sistem layanan kesehatan (Shakibasadeh et.al, 2011). ADA (2015), telah merekomendasikan penangganan diabetes difokuskan pada edukasi tentang upaya manajemen mandiri DM. Pelaksanakan edukasi ditujukan agar pasien patuh terhadap rencana manajemen diabetes dengan memanfaatkan adanya motivasi dan strategi terapi perilaku sebagai salah satu upaya untuk perubahan (Funnel, 2007). Semakin tinggi tingkat pengetahuan seseorang diharapkan semakin tinggi pula kesadaran diri untuk melakukan perubahan. Berdasarkan pemahaman tersebut, peneliti tertarik untuk melakukan penelitian tentang efektifitas edukasi manajemen mandiri terhadap pengendalian kadar glukosa darah diabetesi tipe 2.

\section{METODE PENELITIAN}

Penelitian ini akan dilakukan pada diabetesi tipe 2 yang terdapat di Rumah Sakit Bhakti Wira Tamtama Semarang dengan menggunakan eksperimen kuasi. Penelitian dilakukan dengan mengukur kadar glukosa darah sebelum (pre-test) dan sesudah (posttest) dilaksanakan edukasi manajemen mandiri, rancangan penelitian ini adalah pre test 
post test with control group. Sampel penelitian ditentukan dengan cara purposive sampling dengan memperhatikan kriteria tertentu, yaitu : 1) Bersedia menjadi responden, 2) Kooperatif, 3) Tidak sedang mengalami komplikasi akut DM, dan 4) Mampu membaca dan menulis. Jumlah sampel kelompok intervensi sebanyak 12 responden dan kelompok kontrol 12 responden. Penelitian ini telah lolos uji etik di tim etik Akper Kesdam IV/Diponegoro. Etika penelitian ke responden meliputi informed consent, anonimity, dan independence to refuse.

\section{HASIL DAN PEMBAHASAN}

\section{Hasil Penelitian}

\section{Tabel 1}

Distribusi Responden berdasarkan Usia di Rumah Sakit Bhakti Wira Tamtama Semarang bulan September-November $2016(n=24)$

\begin{tabular}{cccccc}
\hline Kelompok & $\mathbf{n}$ & Mean & Median & SD & Min-Maks \\
\hline Intervensi & 12 & 52,18 & 53,50 & 8,87 & $40-55$ \\
\hline Kontrol & 12 & 51,78 & 53,50 & 8,68 & $41-53$ \\
\hline
\end{tabular}

Tabel 1 menunjukkan rata-rata usia kelompok intervensi adalah 52,18 dengan standar deviasi 8,87, usia terendah kelompok intervensi adalah 40 tahun dan tertinggi usia 55 tahun. Sedangkan, usia rata-rata kelompok kontrol adalah 51,78 dengan standar deviasi 8,68, usia terendah kelompok kontrol adalah 41 tahun dan tertinggi 53 tahun.

Tabel 2

Distribusi Responden berdasarkan Jenis Kelamin, Tingkat Pendidikan, dan Lama DM di Rumah Sakit Bhakti Wira Tamtama Semarang bulan September-November 2016 $(\mathrm{n}=24)$

\begin{tabular}{llcccc}
\hline Variabel & \multicolumn{2}{l}{ Intervensi } & \multicolumn{2}{c}{ Kontrol } & Total \\
\hline & f & \% & f & \% & n \\
\hline Jenis Kelamin & & & & & \\
Laki-laki & 4 & 33 & 5 & 42 & 9 \\
Perempuan & 8 & 67 & 7 & 58 & 15 \\
\hline Tingkat Pendidikan & & & & & \\
SD & 3 & 25 & 4 & 33 & 7 \\
SMP & 3 & 25 & 3 & 25 & 6 \\
SMA & 4 & 33 & 2 & 27 & 6 \\
PT & 2 & 27 & 3 & 25 & 5 \\
\hline Lama Mengalami DM & & & & & \\
$\geq 3$ tahun & 7 & 58 & 8 & 67 & 15 \\
$<3$ tahun & 5 & 42 & 4 & 33 & 9 \\
\hline Jumlah & 12 & 100 & 12 & 100 & 24 \\
\hline
\end{tabular}


Dari tabel 2 dapat diketahui bahwa jumlah responden terbanyak adalah jenis kelamin perempuan baik kelompok intervensi maupun kelompok kontrol, dengan persentase $67 \%$ dan $58 \%$. Sedangkan untuk tingkat pendidikan, persentase tertinggi pada kelompok intervensi adalah SMA $<33 \%$ dan pada kelompok kontrol adalah SD $<33 \%$. Untuk prosentase tertinggi lama mengalami DM adalah $\geq 3$ tahun baik pada kelompok intervensi maupun kelompok kontrol dengan persentase 58\% dan $67 \%$.

Tabel 3

Distribusi Responden berdasarkan Tahapan Perilaku Manajemen Mandiri Pengendalian Glukosa Darah Sebelum Intervensi di Rumah Sakit Bhakti Wira Tamtama Semarang bulan September-November 2016 ( $\mathrm{n}=24)$

\begin{tabular}{lccccc}
\hline Kelompok & $\mathbf{n}$ & Mean & Median & SD & Min-Maks \\
\hline Intervensi & 12 & 2,18 & 2,00 & 1,78 & $1-5$ \\
Kontrol & 12 & 2,58 & 2,00 & 1,68 & $1-5$ \\
\hline
\end{tabular}

Tabel 3 menunjukkan rata-rata tahapan perilaku kelompok intervensi adalah 2,18 dengan standar deviasi 1,78 tahapan perilaku terendah kelompok intervensi adalah 1 dan tertinggi 5. Sedangkan, tahapan perilaku rata-rata kelompok kontrol adala1 2,58 dengan standar deviasi 1,68, tahapan terendah kelompok kontrol adalah 1 dan tertinggi 5.

Tabel 4

Distribusi Responden berdasarkan Tahapan Perilaku Manajemen Mandiri Pengendalian Glukosa Darah Setelah Intervensi di Rumah Sakit Bhakti Wira Tamtama Semarang bulan September-November $2016(n=24)$

\begin{tabular}{lccccc}
\hline Kelompok & $\mathbf{n}$ & Mean & Median & SD & Min-Maks \\
\hline Intervensi & 12 & 4,18 & 3,50 & 1,02 & $1-5$ \\
Kontrol & 12 & 2,88 & 2,48 & 1,87 & $1-5$ \\
\hline
\end{tabular}

Tabel 4 menunjukkan rata-rata tahapan perilaku kelompok intervensi setelah dilakukan intervensi adalah 4,18 dengan standar deviasi 1,02 tahapan perilaku terendah kelompok intervensi adalah 1 dan tertinggi 5. Sedangkan, tahapan perilaku rata-rata kelompok kontrol adalah 2,88 dengan standar deviasi 1,87, tahapan terendah kelompok kontrol adalah 1 dan tertinggi 5. 
Tabel 5

Distribusi Nilai Rata-Rata Kadar Glukosa Darah Sebelum Intervensi di Rumah Sakit Bhakti Wira Tamtama Semarang bulan September-November $2016(\mathrm{n}=24)$

\begin{tabular}{cccccc}
\hline Variabel & Kelompok & Mean & Median & SD & Min-Maks \\
\hline Kadar glukosa & Intervensi & 356 & 345 & 9,88 & $150-520$ \\
darah & Kontrol & 347 & 330 & 9,67 & $142-534$ \\
\hline
\end{tabular}

Dari tabel 5 rata-rata kadar glukosa darah kelompok intervensi adalah 356 dengan standar deviasi 9,88. Kadar glukosa darah terendah kelompok intervensi adalah 150 dan tertinggi 520. Kadar glukosa darah rata-rata kelompok kontrol adalah 347 dengan standar deviasi 9,67, kadar glukosa darah terendah kelompok kontrol adalah 142 dan tertinggi 534.

Tabel 6

Distribusi Nilai Rata-Rata Kadar Glukosa Darah Setelah Intervensi di Rumah Sakit Bhakti Wira Tamtama Semarang di Rumah Sakit Bhakti Wira Tamtama Semarang bulan September-November $2016(n=24)$

\begin{tabular}{|c|c|c|c|c|c|}
\hline$\overline{\text { Variabel }}$ & Kelompok & Mean & Median & SD & Min-Maks \\
\hline Kadar glukosa & Intervensi & 156 & 180 & 9,26 & $105-268$ \\
\hline darah & Kontrol & 354 & 335 & 9,57 & $148-537$ \\
\hline
\end{tabular}

Dari tabel 6 rata-rata kadar glukosa darah kelompok intervensi adalah 156 dengan standar deviasi 9,26. Kadar glukosa darah terendah kelompok intervensi adalah 105 dan tertinggi 268. Kadar glukosa darah rata-rata kelompok kontrol adalah 354 dengan standar deviasi 9,57, kadar glukosa darah terendah kelompok kontrol adalah 148 dan tertinggi 537.

Tabel 7

Uji Normalitas Data Kadar Glukosa Darah Sebelum dan Sesudah Intervensi di Rumah Sakit Bhakti Wira Tamtama Semarang bulan September-November $2016(\mathrm{n}=24)$

\begin{tabular}{ccccc}
\hline Variabel & Kelompok & Mean & SD & Skewness \\
\hline \multirow{2}{*}{$\begin{array}{c}\text { Kadar glukosa } \\
\text { darah }\end{array}$} & Intervensi & & & \\
\cline { 2 - 5 } & Sebelum & 356 & 9,88 & 1,2 \\
\cline { 2 - 5 } & Sesudah & 156 & 9,26 & 0,8 \\
\cline { 2 - 5 } & Kontrol & & & 1,1 \\
\cline { 2 - 5 } & Sebelum & 347 & 9,67 & 1,3 \\
\cline { 2 - 5 } & Sesudah & 354 & 9,57 & \\
\hline
\end{tabular}

Dari tabel 7 dapat dijelaskan bahwa kelompok intervensi sebelum dilakukan intervensi didapatkan mean 356 dengan standar deviasi 9,88 dan nilai skewness 1,2 maka dapat dikatakan nilai tersebut berdistribusi normal karena nilai skewness/SE $-2 \leq$ sampai dengan $\geq 2$. Setelah intervensi didapatkan mean 156 dengan standar deviasi 9,26 dan nilai skewness 0,8 maka dapat dikatakan nilai tersebut berdistribusi 
normal. Pada kelompok kontrol sebelum dilakukan intervensi didapatkan mean 347 dengan standar deviasi 9,67 dan nilai skewness 1,1 maka dapat dikatakan nilai tersebut berdistribusi normal karena nilai skewness/SE $-2 \leq$ sampai dengan $\geq 2$. Setelah intervensi didapatkan mean 354 dengan standar deviasi 9,57 dan nilai skewness 1,3 maka dapat dikatakan nilai tersebut berdistribusi normal.

\section{Tabel 8}

Analisis Perbedaan Kadar Glukosa Darah Sebelum dan Sesudah intervensi pada kelompok intervensi dan kelompok kontrol di Rumah Sakit Bhakti Wira Tamtama Semarang bulan September-November $2016(n=24)$

\begin{tabular}{llcccc}
\hline Variabel & Kelompok & Mean & SD & SE & $\boldsymbol{\rho}$ \\
\hline Kadar glukosa & Intervensi & & & & \\
darah & Sebelum & 356 & 9,88 & 0,23 & 0,004 \\
& Sesudah & 156 & 9,26 & 0,18 & \\
\cline { 2 - 6 } & Kontrol & & & & \\
& Sebelum & 347 & 9,67 & 0,43 & 0,09 \\
& Sesudah & 354 & 9,57 & 0,31 & \\
\hline
\end{tabular}

Tabel 8 Menjelaskan adanya perbedaan kadar glukosa darah $\rho=0.004, \propto<0,05$ ) pada kelompok intervensi. Dari tabel di atas dapat dilihat juga perbedaan penurunan nilai rata rata kadar glukosa darah pada kelompok intervensi sebelum perlakuan adalah 356 dengan standar deviasi 9,88 dan standar error 0,23 sedangan setelah intervensi didapatkan rata rata kadar glukosa darah adalah 156 dengan standar deviasi 9,26 dan standar error 0,18. Dari hasil analisis tabel di atas didapatkan $\rho=0.004, \propto<0,05$ maka dapat disimpulkan adanya perbedaan yang signifikan antara nilai kadar glukosa darah sebelum dan sesudah pemberian intervensi.

Rata rata nilai kadar glukosa darah pada kelompok kontrol pre test didapatkan 347 dengan standar deviasi 9,67 dan standar error 0.43, sedangkan nilai rata-rata post test didapatkan 354 dengan standar deviasi 9,57 dan standar error 0,31. Hasilnya $p=0.09, \propto>0,05$ maka disimpulkan tidak ada perbedaan yang signifikan kadar glukosa darah antara pengukuran sebelum dan sesudah pada kelompok kontrol.

\section{Pembahasan}

Diabetes mellitus merupakan penyakit menahun yang tidak dapat disembuhkan tetapi dapat dikontrol supaya tidak terjadi komplikasi. Hal tersebut menunjukan bahwa pasien DM memerlukan perilaku manajemen mandiriseumur hidup untuk menjaga 
kestabilan kadar glukosa darah. Terdapat banyak faktor yang perlu diperhatikan untuk mengendalikan glukosa darah yaitu kemampuan, keinginan serta upaya untuk melakukan manajemen DM. Diabetesi perlu belajar keterampilan mengendalikan kadar glukosa darah dengan manajemem mandiri DM supaya tidak terjadi komplikasi (Smeltzer dan Bare, 2010). ADA (2012) juga telah merekomendasikan tujuan utama penatalaksanaan DM adalah untuk mencegah terjadinya komplikasi.

Upaya terpenting yang dapat dilakukan untuk mencegah terjadinya komplikasi akut berupa hiperglikemi adalah melibatkan diabetes dalam perawatan dirinya dimana 98\% dari keseluruhan perawatan diabetes tergantung pada perawatan diri sendiri (Anderson, Lutfey, \& Wishner, 2006). Dari pendapat tersebut dapat diambil kesimpulan bahwa kemampuan seorang diabetesi untuk mengendalikan kadar glukosa darah juga tergantung dari diabetesi itu sendiri. Diabetesi perlu mendapatkan dorongan untuk melakukan perubahan perilaku kesehatan sehingga edukasi menjadi prioritas utama. Pengetahuan dan keterampilan diabetesi sangat berpengaruh terhadap perilaku perawatan dirinya sendiri. Kemampuan kognitif diabetesi memiliki hubungan yang signifikan terhadap perilaku dalam manajemen mandiri DM (Carpenter, 2008). Selain kemampuan kognitif, ketersediaan literatur kesehatan khususnya DM juga berpengaruh terhadap kemampuan diabetesi dalam melakukan perawatan diri (Lindley, 2005). Berdasarkan pemahaman tersebut, penggunakan booklet manajemen mandiri diabetes sangat bermanfaat sebagai penunjang media edukasi dengan tujuan memudahkan diabetesi dalam mendapatkan informasi.

Booklet yang digunakan peneliti ini terdiri dari tiga bagian yaitu pengkajian, materi dan evaluasi. Pelaksanaan edukasi membutuhkan perencanaan yang cukup matang sehingga materi yang diberikan dapat diterima oleh diabetesi. Kemampuan diabetesi dalam melakukan manajemen mandiri DM merupakan tujuan utama dari penggunaan booklet ini. Hal yang perlu menjadi pertimbangan adalah manajemen mandiri merupakan konsep yang sangat kompleks sehingga perawat perlu mengetahui bagaimana pandangan diabetesi terhadap sakitnya sehingga perawat perlu mengembangkan pengkajian supaya tepat dalam menggunakan strategi edukasi (Godfrey, 2010). 
Bagian pengkajian dalam booklet terdiri dari riwayat DM meliputi lama sakit, riwayat keluarga dan riwayat manajemen mandiri yang sudah dilakukan. Selain itu, penilaian kesiapan diabetesi dalam pembelajaran juga menjadi bagian dalam pengkajian tersebut. Pengkajian ini dimaksudkan agar perawat dapat menentukan kebutuhan belajar yang diperlukan oleh diabetesi. Diabetesi memerlukan keterampilan serta informasi tingkat dasar, awal, bertahan atau keterampilan tingkat lanjut. Pengkajian ini termasuk observasi langsung terhadap keterampilan diabetesi tidak hanya meminta pasien untuk menjelaskan manajemen mandiri yang dilakukan. Kesiapan diabetesi dan keluarga juga menjadi hal penting dalam pengkajian sehingga perawat dapat menentukan waktu yang tepat untuk melakukan edukasi (Smeltzer\& Bare, 2010).

Bagian kedua memuat tentang informasi yang mencakup keterampilan dan informasi yang bersifat dasar seperti pengetahuan tentang DM, pengaturan diet, pengobatan, pemantauan kadar glukosa darah mandiri serta mengenal tanda dan gejala serta penangganan hiperglikemia dan hipoglikemia. Selain informasi dan keterampilan dasar, bagian ini juga memuat informasi dan keterampilan lanjutan seperti perawatan kaki dan manajemen stress. Bagian ketiga memuat evaluasi serta halaman khusus untuk diabetesi sehingga diabetesi dapat memantau perkembangan manajemen mandiri yang dilakukan dan memiliki dorongan untuk melakukan manajemen mandiri sesuai dengan komitmen yang telah dituliskan pada lembar komitmen.

Hasil penelitian menunjukan perbedaan nilai kadar glukosa darah sebelum dan sesudah dilakukan edukasi manajemem mandiri adalah $\mathrm{p}=0,004, \propto<0,05$ yang berarti bahwa adanya perbedaan yang signifikan antara nilai kadar glukosa darah sebelum dan sesudah pemberian intervensi. Nilai kadar glukosa darah sewaktu setelah dilakukan edukasi rata rata mengalami penurunan $<180 \mathrm{mg} / \mathrm{dl}$, hal ini menunjukan bahwa edukasi manajemen mandiri memberi pengaruh positif dalam perubahan perilaku manajemem mandiri sehingga pengendalian kadar glukosa darah dapat tercapai. Perubahan perilaku dapat dilihat dari penelitian yang menunjukan bahwa setelah dilakukan intervensi terdapat perubahan perilaku pada kelompok intervensi dari rata-rata 2,18 menjadi 4,18. Kriteria perubahan perilaku yang digunakan adalah "1" (precontemplation) atau diabetesi belum mengetahui masalah dan kebutuhan untuk berubah,"2"'(contemplation) atau diabetesi mulai mengerti masalah tetapi belum siap untuk 
berubah,"3"(preparation) atau menyatakan siap untuk berubah,"4"(action) atau sudah melakukan perubahan,"5" (maintaining) atau mempertahankan perubahan yang sudah dilakukan. Dari penelitian ini dapat disimpulkan setelah dilakukan edukasi manajemem mandiri DM, diabetesi termotivasi untuk melakukan perubahan perilaku dari yang semula hanya mengerti masalah meningkat menjadi sudah melakukan perubahan dan hal tersebut membawa nilai positif berupa kemampuan diabetesi untuk mengendalikan kadar glukosa darah.

Selama pelaksanaan penelitian peneliti menemui beberapa hambatan yaitu pelaksanaan edukasi tidak dapat dilakukan dalam satu tempat karena frekuensi edukasi dan cluster daerah sehingga tidak memungkinkan responden datang ke Rumah Sakit Setiap direncanakan edukasi. Upaya yang dilakukan untuk mengatasi masalah tersebut, peneliti membagi menjadi 3 tempat untuk pelaksanaan edukasi yaitu di kelurahan meteseh, kelurahan rowosari dan RST Bhakti Wira Tamtama dengan tujuan mengurangi mobilitas diabetesi. Hambatan berikutnya adalah rata - rata diabetesi yang dirawat memiliki tingkat stress yang cukup tinggi sehingga fokus perhatian berada pada tubuh yang sakit sehingga kesiapan untuk proses pembelajaran memerlukan waktu yang cukup lama. Hal tersebut telah dibicarakan dengan perawat penanggung jawab, solusi yang diambil adalah diabetesi diperkenalkan dulu dengan manajemen stress dengan mengajarkan diabetesi beberapa tehnik reduksi stress dan memberikan kesempatan kepada diabetesi untuk melakukan tehnik yang efektif digunakan untuk masing masing diabetesi. Manajemen stress diberikan lebih awal dengan tujuan diabetesi mampu mengelola stress sehingga diabetesi mampu melanjutkan proses pembelajaran berikutnya untuk topik bahasan yang lain.

\section{KESIMPULAN}

Edukasi menjadi prioritas utama dalam penangganan DM karena pengetahuan dan keterampilan diabetesi sangat berpengaruh terhadap perilaku perawatan diri sendiri. Kemampuan kognitif diabetesi memiliki hubungan yang signifikan terhadap perilaku dalam manajemen mandiri sehingga pengendalian glukosa darah dapat tercapai. Penggunaan booklet sebagai media edukasi terbukti efektif bagi diabetesi dalam mendapatkan informasi dan panduan dalam manajemem mandiri DM. Hal ini perlu ditindaklanjuti oleh pihak pengelola RS atau pelayanan kesehatan yang lain, dengan 
upaya membuat kebijakan, mempertahankan penerapan program ini dengan memperbanyak dan mensosialisasikan ke seluruh ruang perawatan serta melakukan pemantauan agar kualitas layanan semakin berkembang.

\section{DAFTAR PUSTAKA}

Ardakani, M.A., \& Rashidi, M. (2005). Type 2 diabetes and its risk factors. Journal of Rafsanjan University of Medical Sciences. 4(4):348-365.

American Diabetes Association. (2012). Standard of medical care in diabetes 2012. Diabetes Care, January 2012. Vol. 35.

American Diabetes Association. (2015). Standard of medical care in diabetes 2015. Diabetes Care, January 2015. Vol. 38.

Black, J., Hawks J., Keene A. M. (2009). Medical surgical nursing: clinical management for positive outcomes. USA: Elsevier Saunders Company.

Cander, S., Gul, O.O., Gul, C.B., Keles, S.B., Yavas, S., \& Ersoy, C. (2014). The impact of patient education on anthropometric, lipidemic, and glycemic parameters among patients with poorly controlled type II diabetes mellitus. Workplace Health \& Safety. Vol. 62. No.12, 2014.

Dahlan, M.S. (2011). Besar sampel dan cara pengambilan sampel dalam penelitian kedokteran dan kesehatan. Jakarta : Salemba Medika.

Funnel, M. (2007). The Diabetes Attitudes, Wishes, and Needs (DAWN) Study. Clinical Diabetes, 24(4), 154-155.

Guyton, C.A., Hall, J.E. (2007). Textbook of medical physiology. $9^{\text {th }}$ Edition. Philadelphia: W.B Saunders Company.

International Diabetes Federation. (2014). IDF diabetes atlas. $6^{\text {th }}$ Edition Revision 2014.

Lindley, B.J.A. (2005). Self Care : a clarification of meaning and examination of supportive strategies. Diabetes Care, 23(7), 1646-1659.

Perkeni. (2011). Konsensus pengelolaan dan pencegahan diabetes mellitus tipe 2 di Indonesia 2011. Jakarta.

Rodbard, H.W., Jelingger, P.S., Davidson, J.A., Einhorn, D., Garber, A.J., Grunberger, G., Handelsman, Y., Horton, E.S., Lebovitz, H., Levy, P., Moghissi, E.S., \& Schwartz, S.S. (2009). Statement by an American Association of Clinical Endocrinologist / American College of Endocrinology Consensus Panel on Type 2 Diabetes Mellitus: an algoritm for glycemic control. Endocr Pract 2009, Vol 15. 
Shakibasadeh, E., Larijani, B., Shojaeczadah, D., Rashidian, A., Forouzanter, M.H., \& Bartholomew, L.K. (2011). Patient's perpectives on factors that influence diabetes self care. Iranian Journal Public Health. 40(4), 146-158.

Smeltzer \& Bare. (2010). Brunner \& Suddarth's textbook of medical surgical nursing. Philadelpia : Lippincott.

Trouilloud, D. \& Regnier, J. (2013). Therapeutic education among adult with type 2 Diabetes: effects of three days intervention on perceived competence, self management behaviours and glycaemic control. Global Health Promotion. Vol.20, Supp.2, 2013.

Zhaolan, L., Ewen, L.N., Kim, C., Ettner, S.L., Herman, W.H., Karter, A.J., ...Brown, A.F. (2010). Prevalence of chronic complications of type 2 diabetes mellitus out patients-a cross sectional hospital based survey in Urban China. Health and Quality of Life Outcomes, 8(1), 62-67. 